\title{
Turkish Foreign Language Learners' Roles and Outputs: Introducing an Innovation and Role-Playing in Second Life
}

\author{
Cigdem Ozbek \\ Izmir 30 Agustos Secondary School, Turkey \\ Irem Comoglu \\ Dokuz Eylul University, Turkey \\ Bahar Baran \\ Dokuz Eylul University, Turkey
}

\begin{abstract}
This study aims to design of the two activities "introducing an innovation" and "role playing" in Second Life (SL) and to evaluate qualitatively Turkish foreign language learner's roles and outputs before, while, and after the implementation of the activities. The study used community of inquiry model consisting of cognitive presence and social presence as a theoretical frame to discuss the roles and outputs. The participants were twelve students and two English teachers from two different high schools. Teaching and learning in SL took six weeks. The first activity "introducing an innovation" let students develop an innovation and introduce it in English at a congress hall. The second activity "role playing" had four different scenarios in which students would be involved in; travel agency, get permission from family to go out, restaurant, and renting a car. It was found that the two activities in Second Life had various requirements in terms of the teacher, the student and the social environment and that they differed in pre-activity, while-activity and post-activity phases in terms of outputs. When the learning contexts created in this study are considered in terms of cognitive presence, the outcomes of the interaction effect between the teacher, the student, and the social environment were higher in the role-playing activity than in the second activity. Written preparations done before the activity in both teaching activities had positive effects on students' performance during the activity. The fact that students responded to the questions spontaneously without following the scenario and that they found the correct answer through discussion affected their cognitive presence positively. For social presence, the role-play activity resulted in higher social presence than introducing an innovation since the students studied individually in the introduction of an innovation.
\end{abstract}

Keywords: Language education; Technology in foreign language learning; Community of inquiry; Second Life; Role playing

\section{Introduction}

\section{Theoretical Background}

Sociocultural theory, which argues that human mental functioning is a mediated process and that language use, organization, and structure are the primary means of mediation (Lantolf \& 
Thorne, 2006) provides a basis for the usefulness of Second Life (SL) in language learning and teaching. Sociocultural theory can help us understand how language learners develop learning strategies to become competent members of a language learning community (Schieffelin \& Ochs, 1986). At the heart of Vygotskian and sociocultural theory lies the notion of mediation; that is, human activity is developed through social interaction involving the use of tools or signs such as computers and language. According to this view, language acquisition is facilitated through collaborative dialogue and cooperation with peers. Multiuser Virtual Environments (MUVEs) can be considered a useful tool for providing interaction and collaboration among learners (Wang, 2005).

By the same token, the Community of Inquiry Framework (Col), developed by Garrison, Anderson, and Archer (2000) also motivates the uses of SL for English language teaching. Preliminary studies about the use of Col as a framework for SL studies (Burgess, Slate, RojasLeBouef, \& LaPrairie, 2010; McKerlich \& Anderson, 2007; Pellas, 2017) recommended the use of Col in virtual online learning in many other disciplines. Congruent with the work of Dewey (1998) and constructivist approaches, this process model of online learning suggests that worthwhile online learning occurs within a community through the interaction of three core elements: cognitive presence, social presence, and teaching presence. The first main element, cognitive presence, refers to the extent to which the participants in a community of inquiry are able to construct meaning through sustained communication. The second core element, social presence, is the ability of participants in a community of inquiry to project their personal characteristics into the community. The three main aspects of social presence are effective communication, open communication and group cohesion, which help create the conditions for inquiry and quality interaction to achieve educational goals. The third element of the model, teaching presence, performed by the online instructor in an educational setting is the responsibility of supporting and enhancing social and cognitive presence for the purpose of realizing educational outcomes (Garrison, 2007; Garrison, Anderson \& Archer, 2000). It is important to note that these core elements have characteristics in common with the originators of communicative approaches to language teaching, namely, that learners use the target language in a contextualized, meaningful and social environment characterized by interaction.

Communication technologies may also help reduce foreign language learning anxiety which is a serious hindrance to successful learning. As included in Krashen's (1981) Monitor Theory, the affective factors such as anxiety and self-confidence relate directly to language acquisition and can facilitate or impede the language acquisition process. Variables such as lack of motivation, anxiety or low-esteem can create a mental block that prevents comprehensible input from being used. In this sense, Computer-Mediated Communication (CMC) through simulation, MUVEs, gaming and so forth fosters positive affective learning atmospheres, allowing learners to try new behavioral patterns with a minimum of stress (Garcia-Carbonell, Rising, Montero, \& Watts, 2001, p. 486).

\section{The Internet in Foreign Language Education}

The aforementioned aspects, together with the increasing need to provide learners with the opportunity of interacting with other speakers in the target language, may explain the recent mounting interest in the use of computer technologies within the field of foreign language teaching. Son (2011) classifies various online tools used in foreign language education as: 
learning/content management systems; communication; live and virtual worlds; social networking and bookmarking; blogs and wikis; presentation; resource sharing; Website creation; Web exercise creation; Web search engines; dictionaries and concordances; and utilities. Previous studies conducted on the use of online tools and resources for foreign language learning and teaching suggest various advantages. A research study by Fynn and Wigham (2011), for instance, examined the impact of VoiceForum, an asynchronous virtual web platform for oral interaction, on English language learners' oral production in China. The study found out that the platform helped increase students' confidence concerning oral production and encouraged interaction among peers in a context where learners had difficulty in spoken production. Another research study conducted by Berns, Gonzalez-Pardo and Camacho (2013) explored the impact of game-like applications in 3-D virtual environments on language learners' motivation and learning. They concluded that game-like applications in a virtual world provided opportunities for collaboration and interaction and significantly enhanced students' learning experiences. Garrido-Inigo and Rodríguez-Moreno (2015) investigated the effectiveness of the OpenSim platform as a tool in teaching French to tourism students, conducting formative evaluation of students' relevant experiences. The findings indicated that language learning results in reading comprehension, listening comprehension and written expression were positive.

\section{Second Life in Foreign Language Education}

In Second Life, the user creates an avatar that can communicate through voice, text messages, body language and gestures. There are not strict game rules, objectives, roles and environments, which allows the use of Second Life for social networking, education, training and business (Czepielewski, 2011; Salt, Atkins \& Blackall, 2008; Wang \& Braman, 2009). Second Life is naturally social, that is, it requires a socially active community. Several studies have been conducted on the use of Second Life in foreign language learning and teaching, mainly within the framework of task-based learning. Kamali (2012) investigated the anxiety, motivation, and self- confidence of university English preparatory class students in a tasked-based SL activities about English speaking practice. She revealed that students gained motivation and selfconfidence and overcame their anxiety-related problems towards speaking English. In a study by Grant and Huang (2010), language learners were asked to complete tasks collaboratively in the Second Life environment. Survey results indicated that freshmen benefited greatly from collaborative interaction and the scaffolding provided by peers in the virtual platform. Learners in the study also reported that the Second Life experience was useful in gaining cultural experience and improving self-efficacy. In another research study by Jauregi et al. (2011), Spanish language students at B1 proficiency level were expected to communicate synchronously with native speakers in the target language and act collaboratively in the Second Life virtual environment. According to the results of questionnaires and interviews conducted, interaction tasks aimed to enhance effective intercultural communicative competence proved to be beneficial and triggered dynamic instances of oral interaction in Second Life. Wehner, Gump and Downey (2011) investigated the motivation of students in an undergraduate Spanish course using Second Life. They revealed that SL activities decreased student anxiety and increased student motivation to learn Spanish.

It was observed that researchers used different teaching techniques in the SL setting. Most popular of them are problem-based learning (Rogers, 2011), six thinking hats (Gregory \& 
Masters, 2012) and role playing (Gao, Noh \& Koehler, 2009; Rudra, Jager, Aitken, Chang \& Helgheim, 2011; Kamali, 2012; Lin,Wang, Grant, Chien \& Lan, 2014; Wills, Leigh \& Ip, 2011 ;). The most frequently used technique in these studies is role playing in the SL setting.

In sum, previous literature suggests that the use of Multi User Virtual Environments in foreign language teaching has increased recently, revealing positive outcomes. Learners, teacher, teaching strategies and materials are considered to be the most important factors affecting success in these environments.

\section{Rationale for the Study}

The current trend in the field of foreign language education supports the notion that students need to develop some degree of communicative competence, but the actual practices in the language classroom seem to be far from this expected outcome. Unfortunately, teacher talk has typically been found in the past to dominate the foreign language classroom and informal talking and conversation that can encourage communicative proficiency is still not the common pedagogical practice in many settings (Donato \& Mccormick, 1994; Garcia-Carbonell, Rising, Montero, \& Watts, 2001; Smith, 2003; Uztosun, Skinner, \& Cadorath, 2014). In Turkey, two studies analyzing the foreign language education policies in Turkey during 2003-2013 and examining language students and teachers' views proposed that foreign language curricula in Turkey should be arranged because of learners' poor listening and speaking skills and some regulations should be made in the context of students, teachers, teaching programs (Can \& Can, 2014; Ozkan, Karatas, \& Gulsen, 2016). Therefore, the rationale behind this study was the requirement to develop students' speaking and listening skills by using effective language learning activities.

The best language learning takes place when the learner has a genuine reason for language use in a social and interactive environment. In this regard, computer-mediated communication appears to be a beneficial tool for facilitating second language acquisition (SLA) due to its interactive and social nature (Satar \& Ozdener, 2008; Smith, 2003). CMC may increase learner participation, promote social interaction, enhance motivation, increase peer collaboration, and reduce inhibition (Garcia- Carbonell, Rising, Montero, \& Watts, 2001; Ibanez et al., 2011; Peterson, 2006; Smith, 2003; Stevens, 2006).

Apart from learner perspectives, teachers' knowledge of and attitudes toward the use of CMC in language teaching is effective in getting their students to communicate in a foreign language in CMC (Tseng, 2016). Technological Pedagogical Content Knowledge (TPACK) is teachers' knowledge of and attitudes toward technology, pedagogy, and content (Mishra \& Koehler, 2006). Therefore, researchers have been interested in how to develop teachers' TPACK (Mishra \& Koehler, 2006; Tseng, 2016). In this study, teachers and learners used Second Life, one of the most popular 3D MUVES and a modern and advanced form of CMC. SL's effective visual interface and feel of reality are to be some remarkable features of more effective e-learning environments (Mennecke, Triplett, Hassall, Conde \& Heer, 2011). 


\section{The Purpose of the Study}

The current study explores the design of the two activities "introducing an innovation" and "role playing" in Second Life and to evaluate qualitatively Turkish language learner's roles and outputs before, during and after the implementation of the two activities. Despite the fact that role playing is the most frequently used technique in previous studies, this study includes role playing and presentation techniques together, making possible comparisons between the two techniques. The topic of the presentation is "the introduction of an innovation". Innovation in this study means an idea, practice, or object that is perceived as new by an individual or other unit of adaption (Rogers, 2003, p.12). The study strives to find out answers to the following questions:

- What are the roles of the English language teacher, students, and social environment before, during and after introducing an innovation (activity 1 ) in SL?

- What are the roles of the English language teacher, students, and social environment before, during and after role playing (activity 2 ) in SL?

- What are the outputs of implementation of the two techniques (introducing an innovation and role playing) in SL environments?

\section{Methodology}

Foreign language teachers usually try to implement interesting and efficient teaching techniques in their classrooms. They informally evaluate their own teaching and decide to continue to use teaching techniques. However, scientific research is important since they enable researchers and teachers to obtain accurate and reliable information from their environments (Fraenkel \& Wallen, 2001). Researchers studying on technology use in education have tended to conduct qualitative research because of the complexity of new technologies and learning process and the unexplored nature of the new phenomenon (Knupfer, \& McLellan, 1996; Savenye \& Robinson 2003). In addition, 3D-multiuser virtual environments let users communicate one-toone and they require to study in small study groups. Therefore, this research study is based on mainly the case study approach, which is one of the qualitative traditions. Yin (1994) defines case study as "an empirical inquiry that investigates a contemporary phenomenon within its real-life context, especially when the boundaries between phenomenon and context are not clearly evident (p.13). This study includes two case studies because it is focused on the results of implementation of introducing an innovation and role play techniques in SL to develop speaking skill of high school learners. These cases were problem centered and small scale.

\section{Design of the Activities}

The activities to be used for promoting students' speaking skills were determined, considering the opinions of the two English teachers who participated in the current study. During the interviews, the researchers asked the teachers questions about their teaching ways of speaking in English and the problems they face. In the light of the interviews, two Second Life activities were selected: introducing an innovation and role playing daily-life scenarios. 
The SL teaching process took six weeks. In the 1st and 2 nd weeks, the researchers made a presentation about $S L$ and the responsibilities of the two teachers and 12 students during the process. The study group participated in an orientation program in SL. The orientation program included topics about registration, installing SL to personal computers, dressing up, and traveling to different destinations. In the 3rd week, 12 students connected to SL synchronously. After the 3rd week, the students were ready to participate in SL English teaching activities.

Introducing an innovation (activity 1): The responsibility of the students was to develop an innovation and introduce it in English at a congress. The researchers designed a congress room including flexible space and technical utilities such as a table and chairs, pink seats, a stage, spotlights, and a projection screen (Figure 1). An example of an innovation can be a pen including a mirror that can be used as a mascara and eyeliner.

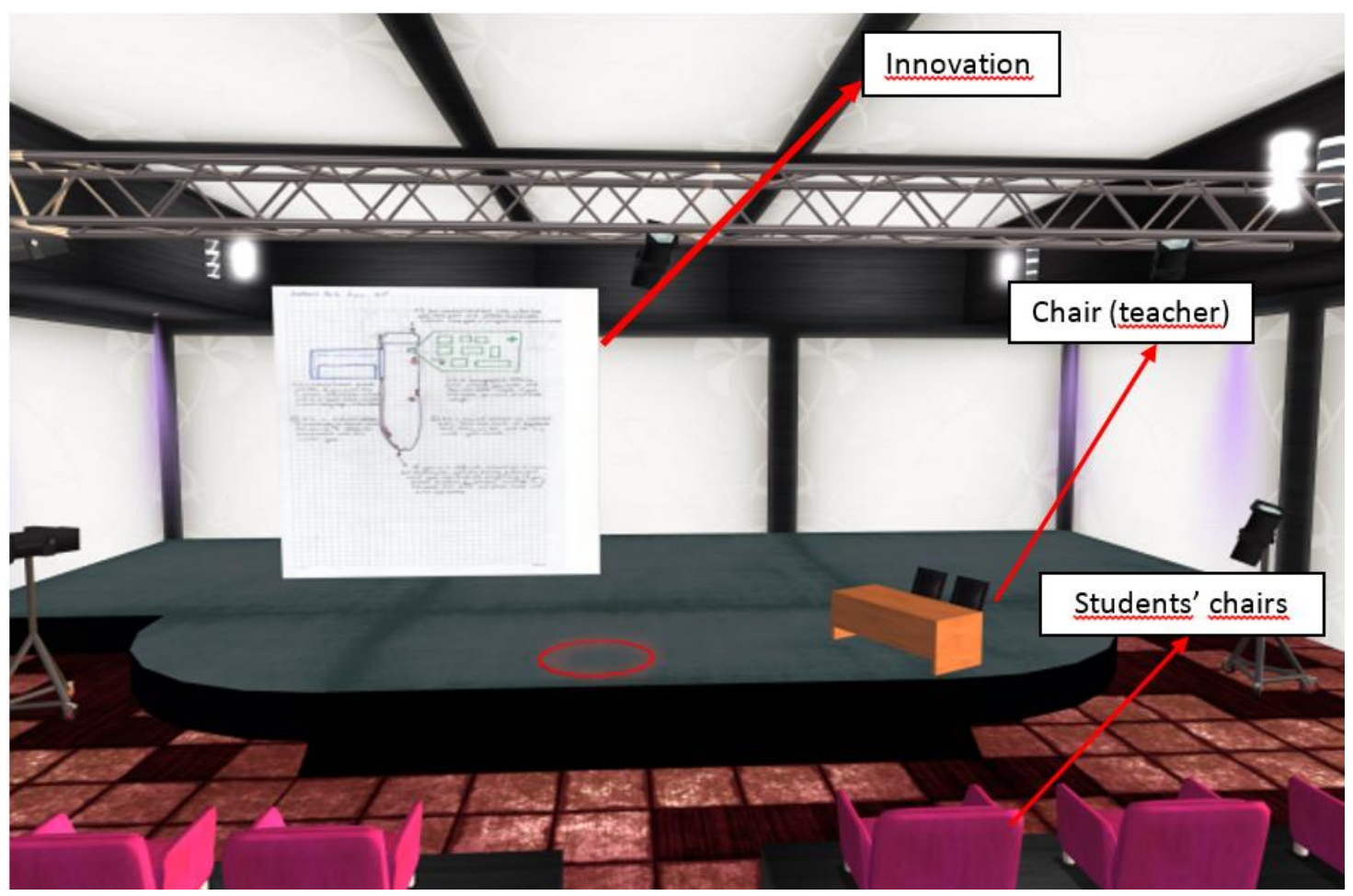

Figure 1. Introducing an Innovation (Activity 1)

Role playing four daily-life scenarios (activity 2): This activity required $4096 \mathrm{~m}^{2} \mathrm{SL}$ field which is divided in four different fields in SL (Figure 2). Four destinations were designed for this activity; travel agency, getting permission from family to go out, restaurant and renting a car. 

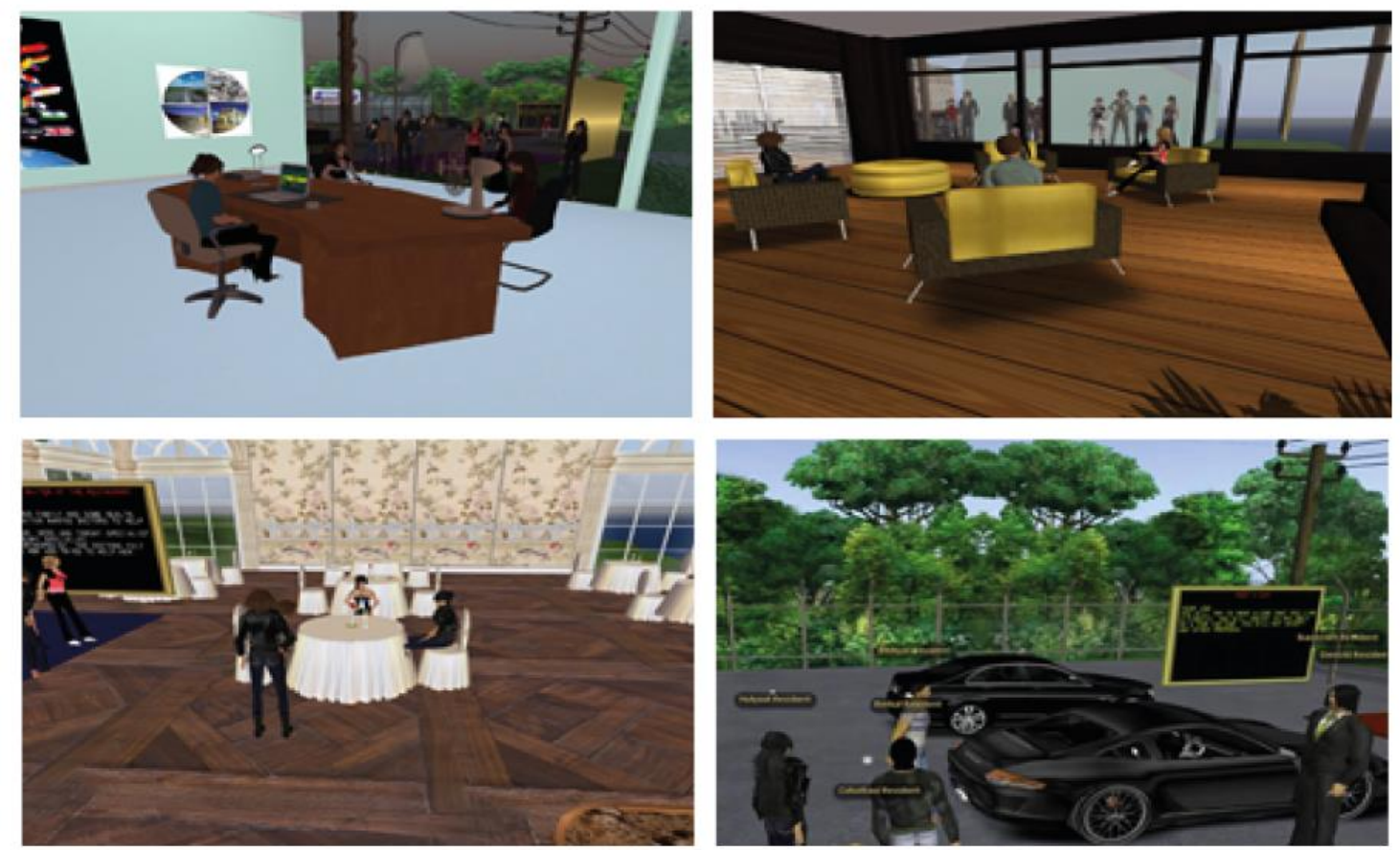

Figure 2. Role-playing (activity 2)

\section{Study Group}

Purposeful sampling method was preferred to determine which schools would be used in the study. The selection of two schools was based on some criteria: a) schools should be located in Izmir/Turkey, b) schools should have a computer laboratory, c) they should have a high-speed Internet access, d) location of two schools should be close, e) school achievements should be similar, and f) students in two schools should have sufficient background to participate in this study. After schools were determined, the selection of students was made according to teachers' opinions and students' willingness to participate. Finally, six students from School-1 and six students from School-2 participated in this study (Table 1).

Table 1. Backgrounds of the Participants

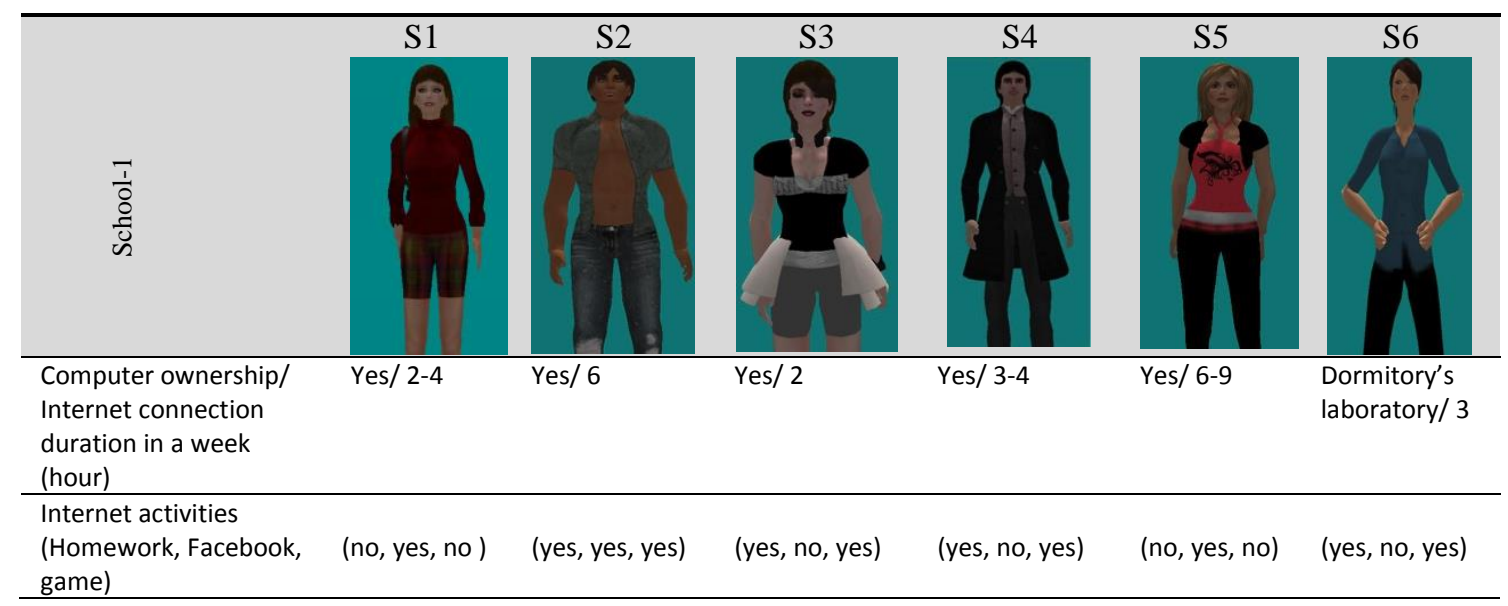




\begin{tabular}{|c|c|c|c|c|c|c|}
\hline Experience & $\begin{array}{l}\text { No prior } \\
\text { experience }\end{array}$ & $\begin{array}{l}\text { Prior } \\
\text { experience } \\
\text { from 3-D } \\
\text { games }\end{array}$ & $\begin{array}{l}\text { No prior } \\
\text { experience }\end{array}$ & $\begin{array}{l}\text { First heard } \\
\text { from TV }\end{array}$ & $\begin{array}{l}\text { Prior } \\
\text { familiarity } \\
\text { from TV }\end{array}$ & $\begin{array}{l}\text { Prior } \\
\text { experience } \\
\text { with SIMS }\end{array}$ \\
\hline \multirow[b]{2}{*}{$\begin{array}{l}\frac{1}{1} \\
0 \\
0 \\
\text { Un }\end{array}$} & S7 & S8 & S9 & S10 & S11 & S12 \\
\hline & & & & & & \\
\hline $\begin{array}{l}\text { Computer ownership } \\
\text { /Internet connection } \\
\text { duration in a week } \\
\text { (hour) }\end{array}$ & Yes /5-6 & Yes/3-4 & Yes /3-4 & Yes /4-5 & Yes /6-7 & Yes / 3 \\
\hline $\begin{array}{l}\text { Internet activities } \\
\text { (Homework, Facebook, } \\
\text { game) }\end{array}$ & $\begin{array}{l}\text { (yes, yes, } \\
\text { yes) }\end{array}$ & (yes, yes, no) & (yes, yes, no) & (yes,yes, no) & (yes,yes,yes) & (yes,yes,yes) \\
\hline Experience & $\begin{array}{l}\text { Prior } \\
\text { experience } \\
\text { from 3-D } \\
\text { games }\end{array}$ & $\begin{array}{l}\text { No prior } \\
\text { experience }\end{array}$ & $\begin{array}{l}\text { No prior } \\
\text { experience }\end{array}$ & $\begin{array}{l}\text { No prior } \\
\text { experience }\end{array}$ & $\begin{array}{l}\text { No prior } \\
\text { experience }\end{array}$ & $\begin{array}{l}\text { No prior } \\
\text { experience }\end{array}$ \\
\hline
\end{tabular}

\section{Data Collection and Analysis}

This study used qualitative data collection methods. Observation, researchers' dairies, semi structured interviews were data collection tools. The researchers conducted in-class observation and computer screen records to collect data about students' behavior in class and on computer. Students' screens were recorded while students participated in the activities. The first activity screen record took 1 hour 50 minutes and the second activity screen record took 1 hour 48 minutes. Interviews were conducted with two English teachers and 12 students. The average teacher interview duration was 34 minutes 5 seconds. The average word count in teacher interviews was 3266 . The researchers conducted three interviews with students. The interviews lasted 5, 19 and 32 minutes, respectively. The average word count was 400, 951, 2854, respectively. In addition, the researchers kept a diary in which they wrote their experiences related to each activity.

The data analysis started with the analysis of "introducing an innovation" activity. Screen records, interviews and dairy notes about this activity were evaluated, simultaneously. The researchers' determined three themes "pre-activity, while-activity and post activity". Then, the data indicated that this activity had some outputs and student roles. The outputs were the participants' perceived benefits from the environment. The researchers searched and recorded all outputs and roles from the data. The Clark and Kozma media and method debate was also useful to frame the data. Clark emphasized the importance of teaching method on learning rather than media while Kozma stated that media including symbol system is important in technology enhanced learning environments (Clark, 1994). So, the two activities were evaluated under two categories "media" (SL) and method ("introducing an innovation" and "role playing"). When the all researchers had a consensus on a code, the code was written under the related theme. Role playing in SL activity was also similarly analyzed. 


\section{Findings}

The analysis of qualitative data gathered from the application of the two activities led to a similar theoretical framework that shows the dynamics of both activities (introducing an innovation and role playing) (Table 2 and 3 ). This theoretical framework suggested a table showing all possible logical relations between pre-activity, while-activity and post-activity phases.

\section{What Happened in "Introducing an Innovation" in SL?}

The first activity which the students experienced was introducing an innovation in SL. The roles and the perceived learning outputs are shown in Table2.

\section{The Roles and Outputs of Pre-activity Phase}

The pre-activity phase indicated that proper preparation before the implementation of this activity was an effective way to implement the activity. The teachers had to design a sample innovation and determine the responsibilities of the students beforehand. Their example was a pen that can be used as a USB device, headphone, and video recorder. Then, they informed students about their responsibilities. The tasks for students were designing another innovation and writing an outline to introduce the innovation to the audience. The students were expected to prepare presentations individually. Since these activities were performed individually, the role of the social environment was not observed before the activity.

The interviews with the teachers indicated that they were satisfied with the use of this activity in SL since they had reached their aims. The preparation before the SL implementation enhanced the imagination of students and improved their vocabulary knowledge. The analysis indicated that the students searched the meanings of technical words related to their innovation. During the preparation, they did not use SL, the effect of media was absent in pre-activity study.

Some participant views were as follows:

We arranged an innovation activity so that students can make sentences of their own, without copying from somewhere else. One week before the activity, students got informed about the activity and requirements (Teacher2).

The innovation activity was really nice. We have always done similar things in our English courses. Yet, we started to do new things in SL, which increase imagination. I had never before talked about a thing I produced. Although it was difficult, I believe it had positive effects on me (Student8).

I designed my innovation myself and searched the English meaning of Turkish words. I want to do the best (Student5).

We were designing a pen during the presentation week. I translated. I just wrote what I had to do. This activity made me study out of school work. I was ready to present as a real presenter because I had studied before coming to SL (Student12). 
Table 2. The Roles, Outputs and Media/Activity Effect in the "Introducing an Innovation" Activity

\begin{tabular}{|c|c|c|c|c|c|}
\hline & The Roles & Observed roles & The Outputs & $\begin{array}{l}\text { MEDIA } \\
\text { EFFECT }\end{array}$ & ACTIVITY \\
\hline \multirow[t]{3}{*}{$\begin{array}{l}\text { Pre- } \\
\text { activity } \\
\text { phase }\end{array}$} & Teacher & $\begin{array}{ll}\text { 1. } & \text { Designs a sample } \\
\text { innovation } \\
\text { 2. } \\
\text { Determines and } \\
\text { mention student } \\
\text { responsibilities }\end{array}$ & \multirow[t]{3}{*}{$\begin{array}{ll}\text { 1. } & \text { Enhancing } \\
\text { imagination } \\
\text { 2. } & \text { Improving } \\
& \text { vocabulary } \\
& \text { knowledge }\end{array}$} & \multirow{4}{*}{ 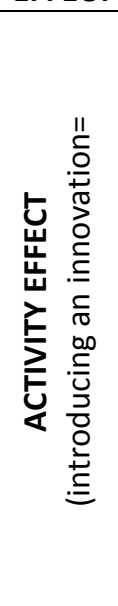 } & \multirow[t]{4}{*}{$\begin{array}{l}\text { Not } \\
\text { observed }\end{array}$} \\
\hline & Student & $\begin{array}{l}\text { Prepares for the } \\
\text { presentation }\end{array}$ & & & \\
\hline & $\begin{array}{l}\text { Social } \\
\text { environment }\end{array}$ & (a) & & & \\
\hline \multirow[t]{3}{*}{$\begin{array}{l}\text { While- } \\
\text { activity } \\
\text { phase }\end{array}$} & Teacher & $\begin{array}{ll}\text { 1. } & \text { Monitors } \\
\text { 2. } & \text { Asks questions } \\
\text { 3. } & \text { Facilitates speaking in } \\
\text { English } \\
\text { 4. } & \text { Provides feedback }\end{array}$ & $\begin{array}{ll}\text { 1. } & \text { Improving } \\
\text { speaking skill } \\
\text { 2. } & \begin{array}{l}\text { Developing self } \\
\text { confidence }\end{array}\end{array}$ & & \\
\hline & Student & $\begin{array}{ll}\text { 1. } & \text { Presents individually } \\
\text { 2. } & \text { Replies questions } \\
\text { 3. } & \text { Asks for help } \\
\text { 4. } & \text { Regulates knowledge }\end{array}$ & $\begin{array}{ll}\text { 3. } & \text { Taking } \\
\text { attention } \\
\text { 4. } & \text { Reducing } \\
\text { tension }\end{array}$ & \multirow{5}{*}{$\begin{array}{l}\text { Not } \\
\text { observ } \\
\text { ed }\end{array}$} & \multirow{5}{*}{$\begin{array}{l}\text { MEDIA } \\
\text { EFFECT } \\
\text { (Second } \\
\text { Life) }\end{array}$} \\
\hline & $\begin{array}{l}\text { Social } \\
\text { environment }\end{array}$ & $\begin{array}{l}\text { 1. Observe presentations } \\
\text { 2. Compare this/her } \\
\text { presentation with } \\
\text { others' Help each } \\
\text { other }\end{array}$ & $\begin{array}{ll}\text { 5. } & \text { Relieving social } \\
\text { pressure } \\
\text { 6. Increasing } \\
\text { motivation }\end{array}$ & & \\
\hline \multirow[t]{3}{*}{$\begin{array}{l}\text { Post- } \\
\text { activity } \\
\text { phase }\end{array}$} & Teacher & $\begin{array}{l}\text { 1. Organizes peer } \\
\text { evaluation } \\
\text { 2. Gives award }\end{array}$ & \multirow{3}{*}{$\begin{array}{l}\text { Making the award } \\
\text { and peer } \\
\text { evaluation more } \\
\text { interesting }\end{array}$} & & \\
\hline & Student & Evaluates peers & & & \\
\hline & $\begin{array}{l}\text { Social } \\
\text { environment }\end{array}$ & $\begin{array}{l}\text { 1. Exchange knowledge } \\
\text { 2. Practice }\end{array}$ & & & \\
\hline
\end{tabular}

\section{Roles and Outputs of While- Activity Phase}

After students and teachers had prepared for the presentation, they signed in to SL for the implementation. During the activities, teachers acted as chairs of the presentation. The presenter had to be on the stage, other students took a seat, examined the presenter's designs projected onto the screen on the stage, and listened to the presentation. Teachers monitored the presenter and other students, asked questions about the innovation, facilitated the presenters' speaking and gave the presenter feedback. The presenter made his/her presentation individually, replied the chairs' questions, asked for help from the chairs, regulated his/her speaking skill. In the social environment, each student observed the presentation and compared his/her own presentation with others' presentation, helped each other when he/she made a mistake.

Introducing an innovation helped develop self-confidence and improve speaking skills such as comprehension and pronunciation. In addition, the findings indicated that the use of SL 
presentation activity increased motivation and interaction, reduced tension, relieved social pressure. Some views are as follows;

Second Life provides socialization in a virtual environment. In addition to learning by doing, students learn many things from their peers and teachers in a social environment. We, as teachers, gave our feedback openly, which helped other students correct their mistakes and acquire appropriate behaviors (Teacher 1).

I was the first to present. The teacher asked questions after the presentation. We had not been informed before that the teachers were going to ask questions. The teacher asked me where I could use the car I had designed. It was an easy question (Student4).

I was happy that week. I believe I made a good presentation. I received positive feedback. The teacher said it was one of his favorite innovations that could be really useful for students, which made me happy (Student 9).

I get too nervous when someone asks me a question. Even if I know the answer, I find it hard to verbalize it. I need to be well-prepared. I believe I can overcome this problem within a few weeks. Therefore, I became happier while listening to others' presentations (Student4).

I had studied at home but I made some pronunciation mistakes. The teacher corrected my pronunciation. I got used to presenting. If you want I can re-present my innovation to you without any mistake (Student4).

The conference hall was amazing with all its details such as chairs and spotlights. It was exciting to be in various environments. In class, there is one environment, but SL offers infinite possibilities (Student5).

\section{Roles and Outputs of Post-activity Phase}

Completing the implementation, teachers and students teleported to out of congress hall and continued to talk in SL about school, lessons or SL environment. Teachers arranged two activities which would increase motivation of students; organizing peer evaluation and giving an award (riding a horse). According to peer evaluation results, students selected the best innovation and presentation. The most successful student's avatar deserved to ride a horse. The students and teachers stated that they found the award and peer evaluation interesting since the owner of the most successful presentation won the award of riding a horse (Figure 3).

Because the teachers asked questions and expressed their opinions, I know how they felt. But I also wonder what my friends thought. I wish students had also expressed their views (Student3).

I didn't expect my innovation to be successful. I became happy that my friends liked it. It was nice to ride a horse. It was also nice to be appreciated (Student3).

Second Life is just like a game. I am enjoying it. It is also nice to ride a horse as an award (Student 1). 


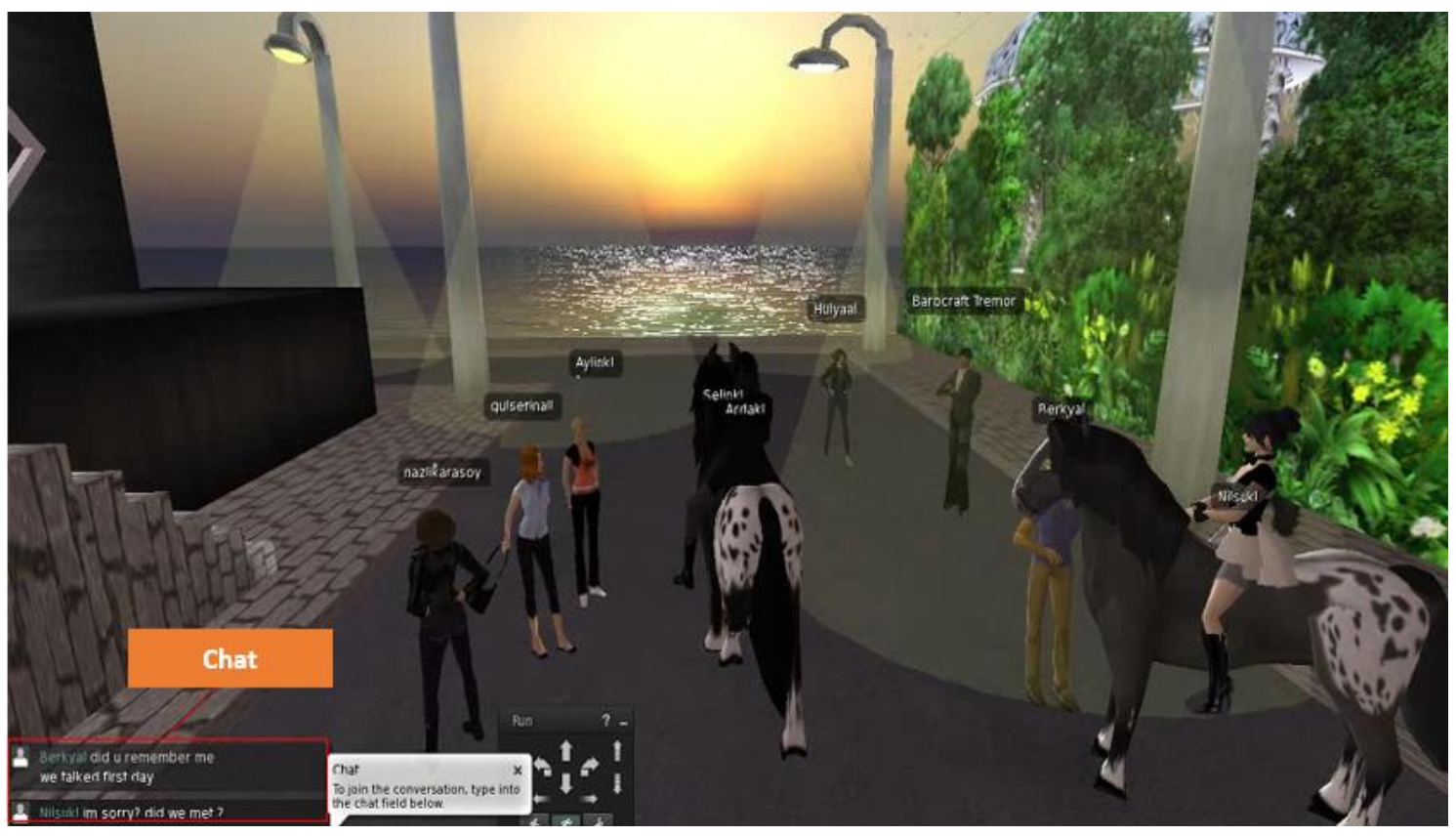

Figure 3. A Screenshot of "Riding a Horse" Award after Peer Evaluation

\section{Problems}

Interaction with the social environment remained somewhat limited in this activity since students presented individually and were not allowed to ask questions to presenters. Students stated that they want to learn what their peers think about their innovation. The screen records indicated that students needed to send private messages to the teachers and peers.

\section{What Happened in Role-playing Activities in SL?}

After the activity of introducing an innovation in SL, students participated in the role playing activity. In this activity, the teacher, student and social environment roles in pre-activity, while activity and post-activity phases were changed. Also, in pre-activity, while activity and postactivity phases, role playing had different outputs (Table 3 ). 
Table 3. The Roles, Outputs and Media/Activity Effect in the "Role Playing" Activity

\begin{tabular}{|c|c|c|c|c|c|}
\hline & The Roles & Observed roles & The Outputs & $\begin{array}{l}\text { MEDIA /A } \\
\text { EFFECT }\end{array}$ & IVITY \\
\hline \multirow{3}{*}{$\begin{array}{l}\text { Pre- } \\
\text { activity } \\
\text { phase }\end{array}$} & Teacher & $\begin{array}{ll}\text { 3. } & \text { Selects the topic } \\
\text { 4. Designs scenarios } \\
\text { 5. Assigns the roles to } \\
\text { students } \\
\text { 6. Checks students' } \\
\text { translation }\end{array}$ & \multirow[t]{3}{*}{$\begin{array}{ll}\text { 3. } & \text { Developing } \\
\text { translation } \\
\text { skills } \\
\text { 4. } \\
\text { Enriching } \\
\text { vocabulary }\end{array}$} & \multirow{5}{*}{ 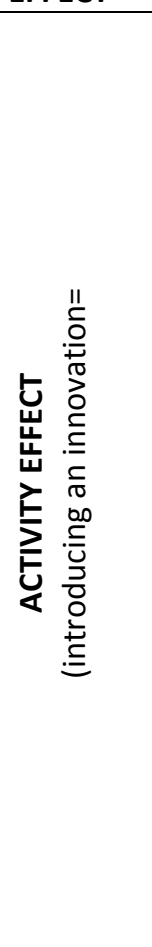 } & \multirow[t]{5}{*}{$\begin{array}{l}\text { Not } \\
\text { observed }\end{array}$} \\
\hline & Student & $\begin{array}{l}\text { Translates as a group } \\
\text { Studies on their roles } \\
\text { individually }\end{array}$ & & & \\
\hline & $\begin{array}{c}\text { Social } \\
\text { environment }\end{array}$ & $\begin{array}{l}\text { Communicate in English } \\
\text { as a group }\end{array}$ & & & \\
\hline \multirow{3}{*}{$\begin{array}{l}\text { While- } \\
\text { Activity } \\
\text { phase }\end{array}$} & Teacher & $\begin{array}{ll}\text { 5. } & \text { Directs dialogs } \\
\text { 6. Encourages } \\
\text { students } \\
\text { 7. Guides them to } \\
\text { speak in English } \\
\text { without } \\
\text { preparation }\end{array}$ & \multirow{2}{*}{$\begin{array}{ll}\text { 7. Improving } \\
\text { listening and } \\
\text { comprehension } \\
\text { skills }\end{array}$} & & \\
\hline & Student & $\begin{array}{ll}\text { 5. } & \text { Starts a dialog } \\
6 . & \text { Improvises } \\
\text { 7. } & \text { Asks for help from } \\
& \text { teacher and peers } \\
\end{array}$ & & & \\
\hline & $\begin{array}{c}\text { Social } \\
\text { environment }\end{array}$ & 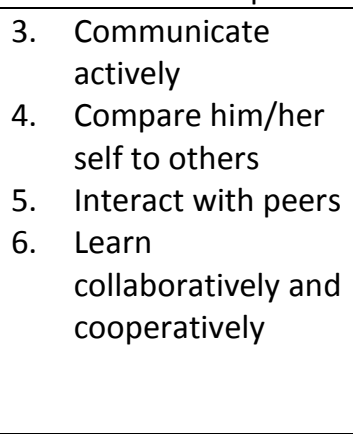 & $\begin{aligned} & 7 . \text { Increased } \\
& \text { sense of reality } \\
& \text { 8. } \\
& \text { Attention } \\
& \text { getting } \\
& \text { 9. } \begin{array}{l}\text { Decreased } \\
\text { social pressure }\end{array} \\
& \text { 10. } \begin{array}{l}\text { Increased } \\
\text { interaction } \\
\text { 11. } \\
\text { Increased } \\
\text { motivation }\end{array}\end{aligned}$ & \multirow[t]{4}{*}{$\begin{array}{l}\text { Not } \\
\text { observed }\end{array}$} & \multirow[t]{4}{*}{ 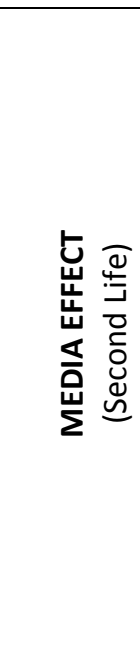 } \\
\hline \multirow{3}{*}{$\begin{array}{l}\text { Post- } \\
\text { activity } \\
\text { phase }\end{array}$} & Teacher & Plans a chat & \multirow{3}{*}{$\begin{array}{l}\text { Developing } \\
\text { speaking skills }\end{array}$} & & \\
\hline & Student & $\begin{array}{l}\text { Participates in } \\
\text { unplanned chat }\end{array}$ & & & \\
\hline & $\begin{array}{c}\text { Social } \\
\text { environment }\end{array}$ & $\begin{array}{l}\text { 3. } \begin{array}{l}\text { Knowledge } \\
\text { sharing/practicing }\end{array}\end{array}$ & & & \\
\hline
\end{tabular}

\section{Responsibilities and Outputs of Pre-activity Phase}

The design of role playing in SL required both teachers and students to study English outside school like the activity of introducing an innovation. Teachers and students had extra responsibilities. The teachers had to select the role playing topics, design scenarios, and assign roles to students. The teachers selected the topic of role playing, prepared role-play dialogs in Turkish and formed student groups. Each student group translated their dialogs into English and each worked on their own roles, individually. The results indicated that some students came 
together a few times in different locations such as a canteen or classroom to achieve the translation task while only one group stated that they had no time to prepare translations because of their exams. The teachers checked the students' translations. Then, the students had to work on the final form of their translations since it would be forbidden to read their roles from the paper during the activity.

The student and teacher views about the pre-activity studies indicated that designing an innovation outside school enriched their vocabulary and developed translation skills owing to doing research about their roles and studying in a group. The interviewees indicated that students used dictionary, discussed their translations with group members. Since teachers and students studied on the design of their roles outside school, the activity only affected students' studies and the effect of media is absent in pre-activity phase. Some students and teachers views are as follows:

I see that we did the right thing by giving them a text to translate into English. They learned about the topic and we corrected their mistakes. I think that it was a well-organized activity (Teacher 1).

It was nice to work in a group. We got closer and practiced together. My English translation skills improved (Student 11).

Since we prepare what we learn and solve problems on our own, we learn better and remember what we learn (Student 8).

Speaking English depends on knowledge of vocabulary rather than of grammar. I learned many new words (Student 8).

\section{Responsibilities and Outputs of While-Activity Phase}

The teachers started each of four scenarios by introducing the actor students. After three students in each group played their roles written in the paper, the teachers continued playing in scenario and talking with them. This activity indicated that the teachers acted as a moderator in role playing. The teachers directed the dialogs, encouraged students in their roles, and guided them to speak without preparation since after one point of the roles, students had to improvise. The students started dialogs in the scenario, actively participated in dialogs and improvised the rest of roles and asked for help from teachers and peers (Figure 4). Lastly, social environment let students set active communication, compare him/herself to others, interact with peers, and learn socially and cooperatively. The students, peers, and their teachers as a social environment communicated in English as a group.

The results of English role playing activity indicated that students had a chance of improving listening and comprehension skills and developing speaking and pronunciation skills. In addition, they believed that this activity let their acquisition transfer to daily life thanks to the role based learning. Lastly, the media (SL) effect was obviously observed during this activity. The media let student feel learning environment more realistic since the teachers could design various learning environments. In addition, these realistic designs increased interest and motivation in English and decreased social pressure to speak in English in a group. In addition, private chatting in SL let students communicate among themselves. 
It was great to see the changes in students' speaking skills. At first, they had it difficult to speak spontaneously, but later they overcame their fear (Teacher2).

I got help from friends during the activities. I asked the meaning of an unknown word. They also helped me when I had difficulty forming sentences. They also asked for my help whey they had any problem with meaning or pronunciation (Student1).

I realized that my focus on sentence form was unnecessary while speaking English. What did I learn from role playing? I learned what is really important: expressing oneself. I can now speak more confidently (Student7).

In class we listened little and spoke very simply. Here in SL, I don't have the chance to ask for repetition, therefore, I am more careful (Student9)

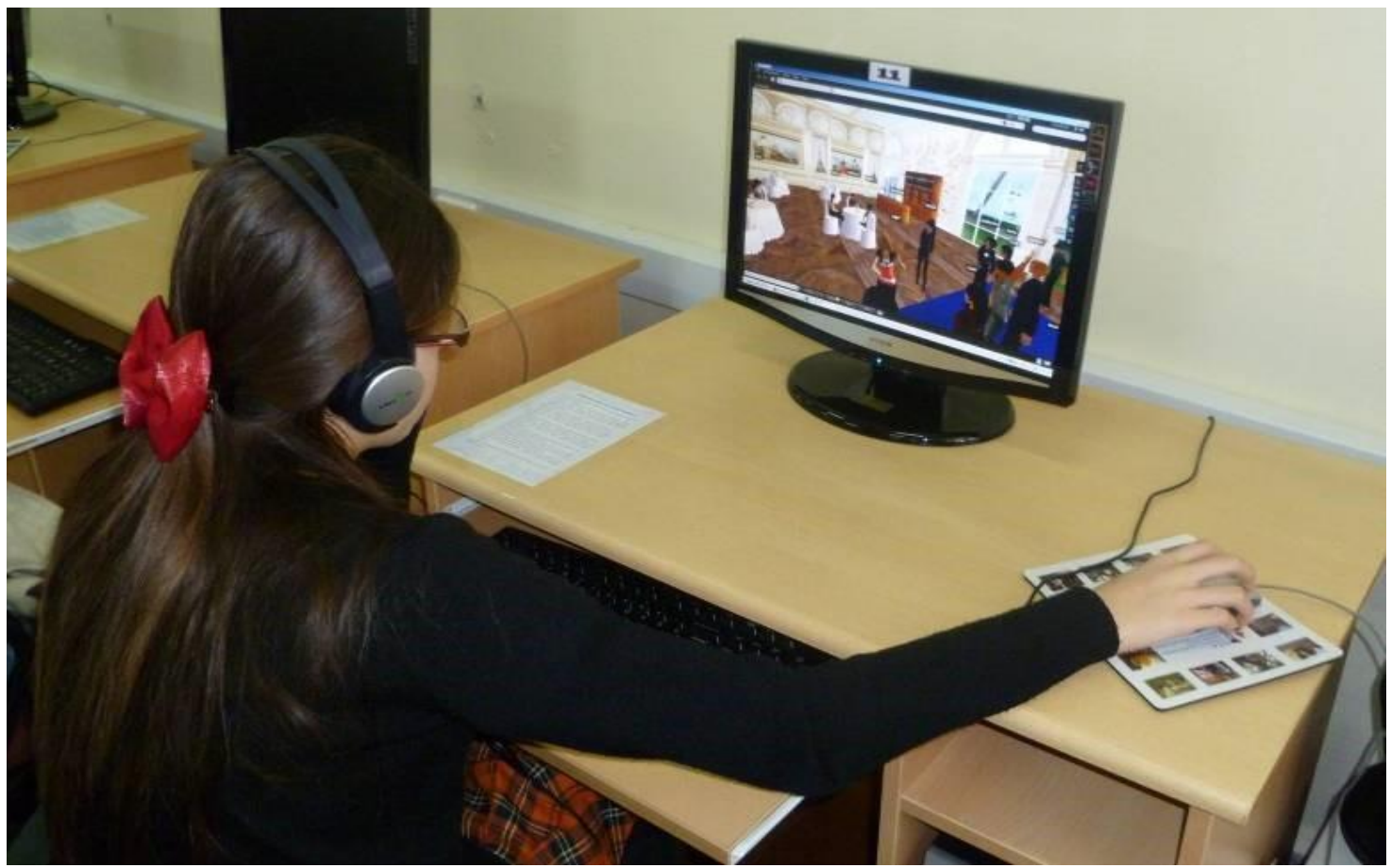

Figure 4. A Screenshot from Student Studying on Restaurant Role-playing

\section{Responsibilities and Outputs of Post-Activity Phase}

After finishing each role playing activity, the teachers planned a 15-minute chat about school activities besides role-plays. This activity was used as a break time between the four role-play scenarios. This post activity also gave teachers and researchers preparation time for the new roles. All students participated in these unplanned chats. In the social environment, they practiced in English without any rule. The teachers stated that these unplanned speaking also improved students' speaking skills. Following chatting, the students were observed to interact with many objects in the environment. They explored the environment, paying special attention to the TV set, fridge, shower, and swing in the home and the cars in the car rental agency. 
Unlike other weeks, last week we did the extra activity in the middle of the activity, not at the end. We planned to do so in order to provide break time for students. This was a time for students to learn unplanned, relax and chat with friends (Teacher1).

Last week in SL, I talked to K5 and K1 most. They told me about their school and holiday plans. My speaking (in English) during the breaks made me happy. In addition, I see I could speak (Student9).

When we were free, we explored the environment, talked about the school and courses (Student2).

I examined the environment. There was a TV set upstairs, for example. My friend turned on the TV. I talked to them and sat across the fireplace. I went to the kitchen and looked into the fridge. I sat in a car at the car rental agency. It was gorgeous! (Student6).

\section{Problems}

Students playing a role in SL faced some problems during the activities. The most repeated problem was the physical (virtual) arrangement of students taking appropriate positions in the SL space. Another problem was that some students considered communication in the virtual environment as a disadvantage since it did not allow the use of gestures and mimics. Also, the move from one scenario to another was time consuming.

\section{Results and Discussion}

Community of inquiry model, in the light of constructivist approaches, emphasizes the importance of effective communication between the teacher and students for better learning outcomes in online courses (Garrison, Anderson, \& Archer, 2000; McKerlich, \& Anderson, 2007; Burgess, Slate, Rojas-LeBouef \& LaPrairie, 2010; Pellas, 2017). In addition, it is evident that the responsibilities of the teachers and learners in online learning environments may be difficult and sometimes complicated. Thus, this study investigated the process of designing and evaluating two different teaching strategies in Second Life as one of multiuser virtual environments, in order to enhance English language learners' speaking skills. It was found out that the two strategies in SL had various requirements in terms of the teacher, students and social environment and that they differed in pre-activity, while-activity and post-activity phases in terms of learning outcomes.

Social presence is related with the ability of explaining yourself in a community. It is quite natural that expressing oneself in a group in another language is a major source of anxiety for many people. Therefore, it is crucial that students feel a sense of belonging in the learning environment. Pellas (2017) investigated the correlation among the elements of Community of Inquiry framework in a course in which higher school students learned programming in OpenSim. The study indicated that social presence has meaningfully correlated with cognitive presence and teaching presence. Another recent study also indicated that learners had experienced high level of social presence in SL (Vrellis, Avouris, \& Mikropoulos, 2016). Similarly, this study indicated that social presence in both activities affected the quality and variability of the outcomes of the implementation of the role-playing and the presentation of an innovation strategies. In addition, the SL communication tools enabled students to talk synchronously and 
send messages in private, which helped them to know each other better. In addition, students found the presentation and role-playing activities quite interesting and close to real life. Therefore, this authentic learning environment decreased their anxiety, reduced social pressure and increased motivation. Similarly, Wehner, Gump and Downey (2011) revealed that virtual worlds were a valuable resource to lower student anxiety and increase their motivation to learn a foreign language. Other studies also yielded some positive outcomes concerning the use of 3D virtual environments in creating authentic learning environments, which cannot be designed in the traditional classroom and in designing meaningful learning activities which are close to real life experiences (Cooke-Plagwitz, 2008; Conde \& Heer, 2011; Dieterle, 2009; Mennecke, Triplett, Hassall).

Furthermore, communication through a virtual identity, an avatar, helped improve studentstudent and student-teacher relationship in this study. It is possible to state that social presence is also high in a real-life context where students choose their favorite avatar and work on speaking. Previous studies suggest that virtual characters representing the student increase social presence (Annetta \& Holmes, 2006). Ozturk and Deryakulu (2011) found that social presence of university students educated in synchronous learning environments is significantly higher than that of their peers educated in asynchronous environments. When the presentation and role-play activities are compared in terms of social presence, it is observed that students in the role-playing activity worked actively and performed the different scenarios through their avatars in small groups, which increased social presence. In the presentation activity, one student was active while the others remained passive and could not ask questions, which led to lower social presence.

Theoretically, the outcomes of implementation of role-playing and presentation of an innovation in Second Life can be connected with cognitive presence, which is defined as students' construction of knowledge collaboratively in online learning environments (Garrison, Anderson, \& Archer, 2000). Cognitive presence reflects the mental aura of the learning environment. It is generally the case that students better construct knowledge in well-led, wellstructured environments with a high level of interaction (Garrison and Cleveland-Innes, 2005). When the learning contexts created in this study are considered in terms of cognitive presence, it is possible to claim that the interaction between the teacher-students and the social environment is higher in the role-playing activity. Ozturk and Deryakulu (2011) indicate that cognitive presence is higher in asynchronous environments than in synchronous environments since students think more densely to produce knowledge. This study used a synchronous communication style, but it was found that written preparations done before the activity in both teaching strategies affected students' performance positively during the activity. Therefore, it is suggested that similar preparation activities should be done while enhancing speaking skills in the SL environment. Considering synchronization, the fact that students responded to the questions spontaneously without following the scenario and that they found the correct answer through discussion affected their cognitive presence positively.

The learning environment designed for this study produced different learning outcomes for real classrooms. First of all, the activities provided the students with real life speaking experiences. Besides, it was found out that the presentation activity improved students' vocabulary knowledge and enhanced their imagination, by making them design an innovation. The role playing activity also improved their vocabulary knowledge. Additionally, it helped students develop their translation skills. In role playing, students translated more and learned more new 
words than in the first activity in daily life scenarios. The learning environment became SL itself during the course. Therefore, it is important to consider learning outcomes during the course within the framework of online learning. The outcomes related to the introducing an innovation activity are as follows: improving speaking skills, developing self-confidence, focusing attention on the lesson, relieving social pressure and reducing tension. The outcomes related to the role play are: improving listening and comprehension skills, transferring knowledge to daily life, improvising the rest of the dialog, developing pronunciation skills, increased sense of reality, increased attention, decreased social pressure, increased interaction and motivation.

Considering the findings of the present study, is possible to make some recommendations to increase social presence in e-learning environments using 3D virtual environments since social presence directly correlated with cognitive presence (Pellas, 2017). First, it is necessary to organize a meeting activity for avatars in contexts where students do not know each other. This meeting activity should continue until students know each other very well, which was not the case in the present study. It might be effective to role play the meeting activity through drama. Second, students should be assigned active roles during the activities. Each should be given the opportunity of expressing oneself in the target language. While the students responsible were performing their duties, the rest can perform the task of understanding and/or writing down what was said. Third, private communication should be allowed during the breaks. This private communication opportunity is important for students especially during free times when they exchange duties. Last, it is important to consider the technological limitations of 3D virtual environments like lack of eye contact in avatars, which decreases the sense of interaction. These solutions could increase student satisfaction.

Findings concerning teachers clearly indicate that a language teacher who wants to help improve students' speaking skills in a virtual environment should be equipped with sufficient knowledge of technology, pedagogy and subject content. Mishra and Koehler (2008) highlight the difficulty of technology use in teaching and state that the teacher should be technologically and pedagogically competent in a positive learning environment that makes use of technology. An English language teacher who wants to teach in the context developed in this study should be able to use Second Life efficiently, search on the Internet and use presentation and word processing programs. Mishra and Koehler $(2006,2008)$ emphasize the importance of using technology knowledge, not superficially, but in a way that relates it to the current content and pedagogical knowledge in order to find solutions to teaching problems. This requires the teacher's use of technology knowledge in problem solving. Based on student achievement in the innovation and role-playing activities designed in the Second Life environment, it can be stated that the teachers in the study applied the appropriate teaching strategies, by combining their pedagogical knowledge concerning speaking skills with their knowledge of technology. It was also observed in the study that the teachers working with the researchers who are information technologies teachers improved their TPACK competence. Previous research confirmed that a specific course focused on technology use helped foreign language teachers combine content, technology and pedagogy to produce better learning outcomes in the classroom (Kurt, Akyel, Kocoglu \& Mishra, 2014; Sancar-Tokmak \& Yanpar-Yelken, 2015). Content analyses concerning TPACK revealed that teachers from various branches also had similar experiences (Baran \& Bilici, 2015; Bilici \& Baran, 2015; Yilmaz, 2015). Therefore, it seems crucial that foreign language teachers develop their TPACK competence through in-service teacher education programs. Furthermore, the findings of the current study suggest that foreign language teachers who are interested to teach speaking skills in the SL environment have the following competencies: 
Pre-course phase: 1) determining the topic, 2) choosing appropriate teaching strategies, 3) knowing the scenario and assigning roles 4 ) introducing duties and roles to students, 4)choosing the context in the SL setting.

While-course phase: 1 ) being active throughout the process, 2) having a role in the scenario, 3) monitoring chats aside from the scenario, 4) giving feedback.

Post-course phase: 1) evaluating the course, 2) giving awards, 3) monitoring chats aside from the scenario.

Community of inquiry model emerges as a model frequently referred to in virtual learning community designs, e-learning environments and blended-learning environments. However, this study differs from the existing literature in that it has used this model in foreign language education, employing different teaching strategies. It is important to indicate that the pedagogical knowledge of teachers is used in the virtual learning communities and the dynamics related to them are revealed. For this reason, it may be advisable to design different educational technologies in which the community of inquiry models and teaching strategies are used.

This study had some limitations that should be taken into consideration in the following studies. This study was conducted during the additional school hours of the students who wanted to participate in the activity. Working with a different group of students instead of these students who receive language education will possibly produce different results. Also, the students' limited experience of 3D environment dynamics may have affected the findings. Working with students who are more experienced may produce different results. Finally, although this study was designed as a qualitative study, it might be useful to use quantitative measures as well to evaluate the teaching strategies used in the community of inquiry.

\section{References}

Annetta, L. A. \& Holmes, S. (2006). Creating presence and community in a synchronous virtual learning environment using avatars. International Journal of Instructional Technology and Distance Learning, 3(8), 27-43.

Baran, E. \& Bilici, S. C. (2015). A Review of the research on technological pedagogical content knowledge: The case of Turkey. Hacettepe University Journal of Education, 30(1), 15-32.

Berns, A., Gonzalez-Pardo, A., \& Camacho, D. (2013). Game-like language learning in 3-D virtual environments. Computers \& Education, 60(1), 210-220.

Bilici, S. C. \& Baran, E. (2015). The investigation of science teachers' self-efficacy toward technological pedagogical content knowledge: A longitudinal study. Journal of Gazi Faculty of Education, 35(2), 285-306.

Burgess, M. L., Slate, J. R., Rojas-LeBouef, A., \& LaPrairie, K. (2010). Teaching and learning in Second Life: Using the Community of Inquiry (Col) model to support online instruction with graduate students in instructional technology. The Internet and Higher Education, 13(1), 84-88. 
Can, E. \& Can, C. I. (2014). Turkiye'de ikinci yabanci dil ogretiminde karsilasilan sorunlar [Problems Encountered in Second Foreign Language Teaching in Turkey]. Trakya University Journal of Education, 4(2), 43-63.

Clark, R. E. (1994). Media and method. Educational Technology. Research \& Development 42(3), 7-10.

Cooke-Plagwitz, J. (2008). New directions in CALL: An objective introduction to Second Life. CALICO Journal, 25(3), 547-557.

Czepielewski, S. (2011). The virtual world of second life in foreign language learning. In S. Czepielewski (Ed.), Learning a language in virtual worlds (pp.15-24). Warsaw: Warsaw Academy of Computer Science.

Dewey, J. (1998). Experience and education. New York: Kappa Delta Pi.

Dieterle, E. (2009). Multi-User virtual environments for teaching and learning. In M. Pagani (Ed.), Encyclopedia of multimedia technology and networking (2 ${ }^{\text {nd }}$ ed.) (pp. 1033-1041). Hershey, PA: Information Science Reference. doi:10.4018/978-1-60566-014-1.ch139

Donato, R. \& McCormick, D. (1994). A sociocultural perspective on language learning strategies: The role of mediation. The Modern Language Journal, 78(4), 453-464.

Fraenkel, J. R. \& Wallen, N. E. (2001). How to design and evaluate research in education. Mahwah, NJ: Lawrence Erlbaum.

Fynn, F. \& Wigham, C. R. (2011). The" VoiceForum" Platform for Spoken Interaction. Proceedings of the European Association for Computer-Assisted Language Learning (EuroCALL) Annual Conference (pp.55-58). Nottingham, UK.

Gao, F., Noh, J.J., \& Koehler, M.J. (2009). Comparing role-playing activities in Second Life and face-to-face environments. Journal of Interactive Learning Research, 20(4), 423-443.

García-Carbonell, A., Rising, B., Montero, B., \& Watts, F. (2001). Simulation/gaming and the acquisition of communicative competence in another language. Simulation \& Gaming, 32(4), 481-491.

Garrido-Inigo, P. \& Rodríguez-Moreno, F. (2015). The reality of virtual worlds: Pros and cons of their application to foreign language teaching. Interactive Learning Environments, 23(4), 453-470.

Garrison, D. R. (2007). Online community of inquiry review: Social, cognitive, and teaching presence issues. Journal of Asynchronous Learning Networks, 11(1), 61-72.

Garrison, D. R. \& Cleveland-Innes, M. (2005). Facilitating cognitive presence in online learning: Interaction is not enough. The American Journal of Distance Education, 19(3), 133-148.

Garrison, D. R., Anderson, T., \& Archer, W. (2000). Critical inquiry in a text-based environment. The Internet and Higher Education, 2(2), 87-105.

Grant, S. \& Huang, H. (2010). The integration of an online 3D virtual learning environment into formal classroom-based undergraduate Chinese language and culture curriculum. Journal of Technology and Chinese Language Teaching, 1(1), 2-13.

Gregory, S. \& Masters, Y. (2012). Real thinking with virtual hats: A role- playing activity for preservice teachers in Second Life. Australasian Journal of Educational Technology, 28 (special issue 3), 420-440. 
Ibáñez, M. B., García, J. J., Galan, S., Maroto, D., Morillo, D., \& Kloos, C. D. (2011). Design and implementation of a 3D multi-user virtual world for language learning. Journal of Educational Technology \& Society, 14(4), 2-10.

Jauregi, K., Canto, S., de Graaff, R., Koenraad, T., \& Moonen, M. (2011). Verbal interaction in Second Life: towards a pedagogic framework for task design. Computer Assisted Language Learning, 24(1), 77-101.

Kamali, T. (2012): Students' experiences and perceptions of anxiety, motivation, and selfconfidence in speaking English during task-based language learning activities in Second Life: The case of METU (Unpublished master's thesis). Middle East Technical University, Ankara, Turkey.

Knupfer, N. N. \& McLellan, H. (1996). Descriptive research methodologies. In D. H. Jonassen (Ed.), Handbook of research for educational communications and technology (pp.11961212). New York: Macmillan.

Krashen, S. D. (1981). Second language acquisition and second language learning. Oxford, UK: Pergamon.

Kurt, G., Akyel, A., Kocoglu, Z., \& Mishra, P. (2014). TPACK in practice: A qualitative study on technology integrated lesson planning and implementation of Turkish pre-service teachers of English. ELT Research Journal, 3(3), 153-166.

Lantolf, J. P. \& Thorne, S. L. (2006). Sociocultural theory and the genesis of L2 development. Oxford: Oxford University Press.

Lin, T. J., Wang, S. Y., Grant, S., Chien, C. L., \& Lan, Y. J. (2014). Task-based teaching approaches of Chinese as a foreign language in Second Life through teachers' perspectives. Procedia Technology, 13, 16-22.

McKerlich, R. \& Anderson, T. (2007). Community of inquiry and learning in immersive environments. Journal of Asynchronous Learning Networks, 11(4), 45-52.

Mennecke, B. E., Triplett, J. L., Hassall, L. M., Conde, Z. J., \& Heer, R. (2011). An examination of a theory of embodied social presence in virtual worlds. Decision Sciences, 42(2), 413450 .

Mishra, P. \& Koehler, M. (2006). Technological pedagogical content knowledge: A framework for teacher knowledge. Teachers College Record, 108(6), 1017-1054. doi:10.1111/j.14679620.2006.00684.x

Mishra, P. \& Koehler, M. (2008). Introducing technological pedagogical content knowledge. Paper presented at the Annual Meeting of the American Educational Research Association. New York.

Ozkan, E. S., Karatas, I. H., \& Gulsen, C. (2016). Turkiye'de 2003-2013 yillari arasinda uygulanan yabancı dil egitimi politikalarinin analizi [The analysis of foreign language education policies in Turkey during 2003-2013]. Journal of Research in Education and Teaching, 5(1), 245-254.

Ozturk, E. \& Deryakulu, D. (2011). The effect of type of computer mediated communication tools on social and cognitive presence in online learning community. Hacettepe University Journal of Education, 41(41), 349-359. 
Pellas, N. (2017). An exploration of interrelationships among presence indicators of a community of inquiry in a 3D game-like environment for high school programming courses. Interactive Learning Environments, 25(3), 343-360.

Peterson, M. (2006). Learner interaction management in an avatar and chat-based virtual world. Computer Assisted Language Learning, 19(1), 79-103.

Rogers, E. M. (2003). Diffusion of innovation. New York: Free Press.

Rogers, L. (2011). Developing simulations in multi-user virtual environments to enhance healthcare education. British Journal of Educational Technology, 42(4), 608-615.

Rudra, A., Jaeger, B., Aitken, A., Chang, V., \& Helgheim, B. (2011).Virtual team role play using Second Life for teaching business process concepts. Paper presented at 44th Hawaii International Conference System Sciences (HICSS). Hawaii, USA, 1-8.

Salt, B., Atkins, C., \& Blackall, L. (2008). Engaging with SecondLife: Real education in a virtual world literature review, SLENZ Project. Retrieved on 3 July 2017 from http://piensl. pbworks.com/f/slliteraturereviewa1.pdf.

Sancar-Tokmak, H. \& Yanpar-Yelken, T. (2015). Effects of creating digital stories on foreign language education pre-service teachers' TPACK self-confidence. Educational Studies, 41(4), 444-461.

Satar, H. \& Ozdener, N. (2008). The effects of synchronous CMC on speaking proficiency and anxiety: Text versus voice chat. The Modern Language Journal, 92(4), 595-613.

Savenye, W. C. \& Robinson, R. S. (2003). Qualitative research issues and methods: an introduction for educational technologies. In David H. Jonassen (Ed.). Handbook of research for educational communications and technology (pp.1045-1071). New York: Macmillan.

Schieffelin, B. B. \& Ochs, E. (1986). Language socialization across cultures (No. 3). Cambridge: Cambridge University Press.

Smith, B. (2003). The use of communication strategies in computer-mediated communication. System, 31(1), 29-53.

Son, J. B. (2011). Online tools for language teaching. TESL-EJ, 15(1), 1-12.

Stevens, V. (2006). Second Life in education and language learning. TESL-EJ, 10(3), 1-4.

Tseng, J. J. (2016). Developing an instrument for assessing technological pedagogical content knowledge as perceived by EFL students. Computer Assisted Language Learning, 29(2), 302-315.

Uztosun, M. S., Skinner, N., \& Cadorath, J. (2014). An action research study designed to implement student versus voice chat. The Modern Language Journal, 92(4), 595-613.

Vrellis, I., Avouris, N., \& Mikropoulos, T. A. (2016). Learning outcome, presence and satisfaction from a science activity in Second Life. Australasian Journal of Educational Technology, 32(1).

Wang, C. H. (2005). Questioning skills facilitate online synchronous discussions. Journal of Computer Assisted Learning, 21, 303-313

Wang, Y. \& Braman, J. (2009). Extending the classroom through Second Life. Journal of Information Systems Education, 20(2), 235-247. 
Wehner, A. K., Gump, A. W., \& Downey, S. (2011). The effects of Second Life on the motivation of undergraduate students learning a foreign language. Computer Assisted Language Learning, 24(3), 277-289.

Wills, S., Leigh, E., \& Ip, A. (2011). The power of role-based e-learning. New York: Routledge.

Yin, R. K. (1994). Case study research: Design and methods ( $2^{\text {nd }}$ ed.). London: Sage.

Yilmaz, G. K. (2015). Analysis of technological pedagogical content knowledge studies in Turkey: A Meta-Synthesis Study. Education and Science, 40(178), 103-122.

Correspondence: Bahar Baran, Associate Professor, Department of Computer Education and Instructional Technologies, Buca Faculty of Education, Dokuz Eylul University, Izmir, Turkey 